\title{
Anthrovision
}

Vaneasa Online Journal

\section{An Expected Revolution? Visuality, autodefensas, and Imaginaries of Citizens' Self-protection in Mexico}

\section{Gabriela Zamorano Villarreal}

\section{(2) OpenEdition \\ 1 Journals}

Electronic version

URL: http://journals.openedition.org/anthrovision/3861

DOI: 10.4000/anthrovision.3861

ISSN: 2198-6754

Publisher

VANEASA - Visual Anthropology Network of European Association of Social Anthropologists

\section{Electronic reference}

Gabriela Zamorano Villarreal, « An Expected Revolution? Visuality, autodefensas, and Imaginaries of Citizens' Self-protection in Mexico », Anthrovision [Online], 6.2 | 2018, Online since 31 December 2018, connection on 04 September 2019. URL : http://journals.openedition.org/anthrovision/3861 ; DOI : 10.4000/anthrovision.3861

This text was automatically generated on 4 September 2019

(c) Anthrovision 


\title{
An Expected Revolution? Visuality, autodefensas, and Imaginaries of Citizens' Self-protection in Mexico
}

\author{
Gabriela Zamorano Villarreal
}

\section{Introduction}

In February 2013, localities affected by narco-violence in Michoacán, Mexico, organized themselves into autodefensa groups, effectively constituting an armed movement to confront abuses of the cartels operating in the region. This movement, which built on previous experiences of community police initiatives in Michoacán and Guerrero, soon gained a presence among national and international mainstream and independent media. Its appeal for "self-protection" gained sympathy among both entrepreneurial classes and popular and peasant sectors.

2 This article does not examine the autodefensa groups in themselves, but rather seeks to understand how the production and circulation of images around this movement, such as press photography and video spots, has echoed certain notions of citizenship as selfprotection in Mexico; and how these notions are nourished by historical fantasies about the armed peasant as central agent of political transformation. I analyse two groups of images aimed at reaching two different kinds of publics. First, I show how the figure and rhetoric of José Manuel Mireles, one of the most important self-defense groups' leaders, became central for the political party Movimiento Ciudadano's initiative "Frente Nacional de Autodefensa de México" (National Front of Self-defense of Mexico) in 2014. Such an initiative spoke, to a great extent, to the interests of entrepreneurs who felt threatened by the cartels' campaign of extortion and kidnapping. Second, I analyse a series of press photographs about self-defense groups that appeared in national and international media, and which addressed left urban sectors' sympathy for rural armed movements. Although produced and circulated for very different political purposes and publics, I suggest that both groups of images reinforce a similar rhetoric of citizenship. At the same 
time, both groups of images build on historical imaginaries and fantasies about peasants as central agents of political transformation in Mexico. My focus on visual forms related to the self-defense movement allows for an exploration of affective and aesthetic fields that in many ways are contributing to collective reelaborations of citizenship, and which do not necessarily belong to the realm of organized and legal action. In which ways does the circulation of these kinds of images in the public sphere mobilize collective affects and fantasies of future, and how does this mobilization relate to an inconsistent but effective neoliberal "common sense" (Leal 2016) to conceive citizenship as "selfprotection"? The analysis includes a preliminary exploration of the ways in which these images engage with the reelaborations that the current, populist government of President Andrés Manuel López Obrador is making of citizenship and security as part of the new state project.

\section{Are We all autodefensas?}

In the first months of 2013, people living in various regions affected by narco-violence in Michoacán organized themselves into autodefensas or self-defense groups. Seeking strategies to confront cartel abuses such as extortion, kidnapping and killing, these groups obtained weapons and developed mechanisms such as identifying and capturing cartel members, organizing community surveillance strategies, blocking access to people associated with the cartels in specific localities, and collaborating with federal forces to arrest cartel members.

4 This movement was based in previous experiences of local surveillance and community police, in places such as Ostula in 2009 and Cherán in 2011 in Michoacán (Maldonado 2014; Guerra 2015), as well as various community police experiences in Guerrero. These recent initiatives built on more traditional forms of community police through figures like topiles or rotating policemen that operate in many Mexican rural communities as part of the cargo system that dates from colonial times. As Guerra Manzo notes, the autodefensas movement in Michoacán has raised numerous public reactions that range from suspicions of a paramilitary phenomenon, to their explanation as a necessary social movement that responds to the failure of the state to protect its citizens (Guerra 2015). This latter explanation relates to the fact that current narco-violence frequently results in an oft-frustrated need to exercise citizenship rights.

5 In May 2014, a video presenting the "Frente Nacional de Autodefensa de Mexico" started to circulate on the internet. ${ }^{1}$ It combined the Zapatista Army of National Liberation slogan "Todos somos Marcos" ("We are all Marcos") with the aesthetics of another 2012 video middle-class students produced to protest against the presidential candidacy of Enrique Peña Nieto, "Yo soy 132" (I am 132). ${ }^{2}$ In both videos, people presented themselves and their political position speaking directly to the camera. 


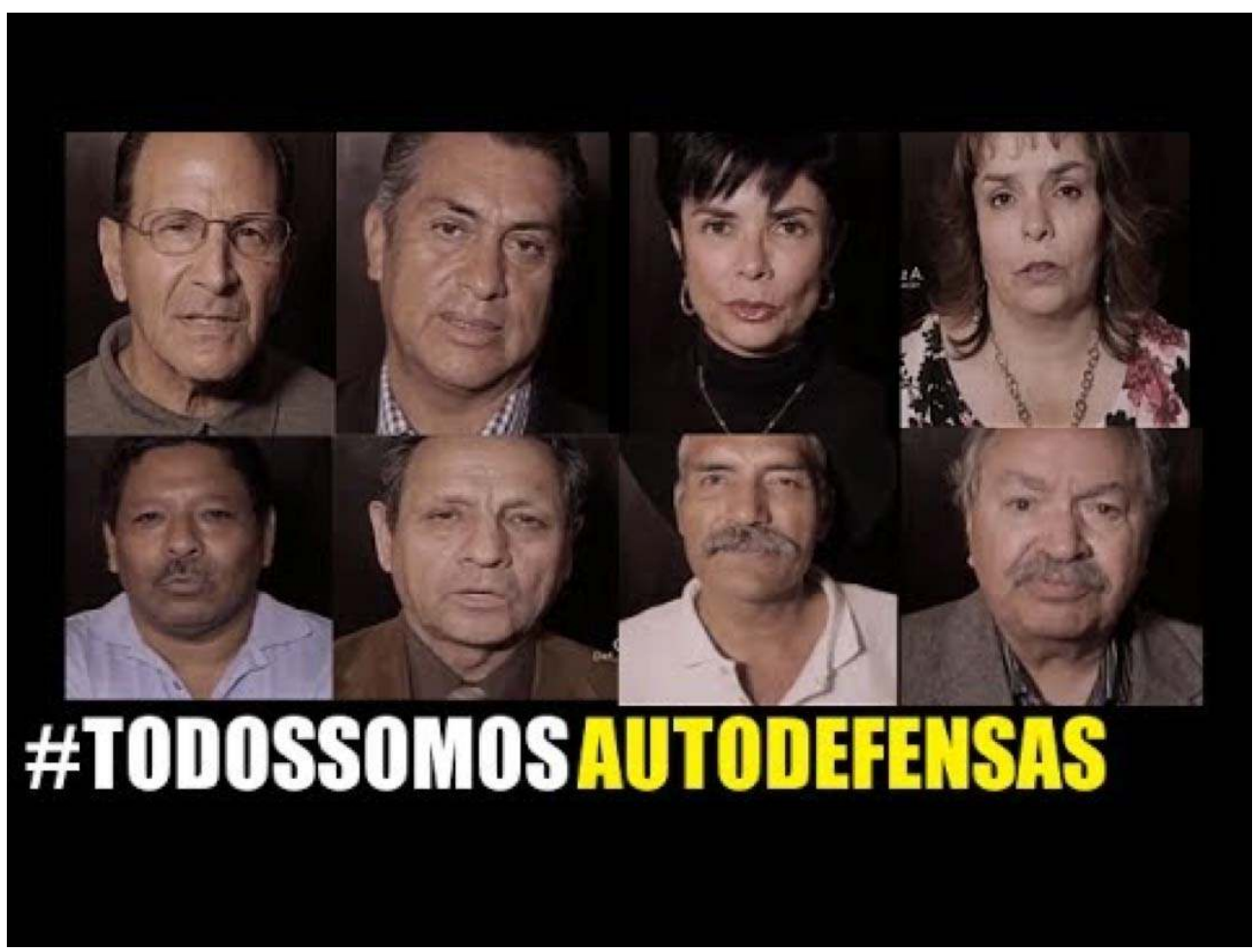

Frente Nacional de Autodefensas, 2014. Youtube. 2 min.

https://www.youtube.com/watch?v=QYoGTcYq0Z8 (accessed June 30, 2019).

6 The Frente Nacional de Autodefensa de Mexico's video is only two minutes long. It introduces, one by one, ten political personalities from different regions of Mexico, who briefly explain their reasons for identifying themselves as "autodefensas" and supporting the self-defense movement of Michoacán, reasons that range from being tired of impunity and injustice, to the need to protect their own families. The presenters have heterogeneous profiles that include Priest Alejandro Solalinde, who has a solid trajectory in the defence of Central American migrants' rights; the controversial former governor of Nuevo León state and "independent" presidential candidate Jaime Rodríguez Calderón "El Bronco"; as well as lawyers and businessmen whose relatives have been kidnapped. Each presenter speaks with an emotional and direct tone facing the camera, with a careful sepia illumination, while a sweet piano music dramatizes the effect of their voices. The last presenter is José Manuel Mireles. As if suggesting that he is the true or original autodefensa, Mireles conclusively invites the public to adhere to the movement by stating, together with the repetitive echoes of each presenter: "I am autodefensa, we are all autodefensas".

7 The "Frente Nacional de Autodefensa" emerged among representatives of various civil society sectors and José Manuel Mireles in May 2014 in Mexico City. Mireles was by then the most important representative of the Michoacán state autodefensa movement. The first Front meeting aimed to create support for the self-defense movement in Michoacán, while centering on a discourse emphasizing citizens' power. $^{3}$

8 When preparing the meeting in Mexico City, Priest Alejandro Solalinde declared to the press: "Many of us are already defending ourselves and would like to start a strong and plural movement throughout the country with a very clear goal: to defend ourselves 
amongst all of us, because the government is not doing that". ${ }^{4}$ Based on a discourse of citizenship, this initiative calls for gathering the many different reasons and causes of injustice and state neglect in Mexico and argues for the need of self-protection in face of the state's inability to protect its citizens. It is not coincidental that most of the "civil society representatives" that appear in the video that resulted from the meeting were related, directly or indirectly, to Movimiento Ciudadano, a recently funded political party which mobilizes the argument of citizenship power to transform the conditions of violence and inequality in Mexico.

Nevertheless, a common issue among most of the "representatives" who appear in the video is their middle and upper-class position: many of them are business people, government officials, journalists and civil society representatives who, after having lived through kidnaps and killings of their relatives, became spokespeople for the fight against kidnapping in Mexico. The fact that all these different political actors became allies at that moment around the self-defense movement, presenting José Manuel Mireles as their caudillo or leader, generates several questions: Why would Mireles and the self-defense groups, as opposed to other struggles, lead this citizens' movement? What were the implications or advantages for these mainly urban representatives, of uniting around a rural armed movement?

In June 2014, one month after the Front was established, Mireles, together with other 83 members of the self-defense movement, were arrested by forces of the federal government while they sought to fight organized crime in localities in the Lázaro Cárdenas municipality. They were accused of illegally carrying firearms. After their arrest, actors affiliated to the Movimiento Ciudadano political party, such as Mireles' lawyer Thalía Vázquez, headed the mobilization for his liberation. This mobilization included a photographic and video campaign with a similar aesthetic to the one used in the video "Todos somos Autodefensas", most probably designed by the same producers, which equally emphasized the notion of citizenship as the vector of the struggle. ${ }^{5}$

11 By discussing how video and photography were deployed during the first years of the self-defense movement to strengthen a call for exercising citizenship in Mexico I do not mean to ignore the tremendous conditions of violence and abuse that have compelled people to create different self-defense groups. I do not seek either to dwell on the contradictions of the Movimiento Ciudadano political party that sought to gain legitimacy and visibility through a discourse of citizens' self-protection. Nevertheless, the ways in which this party mobilized the idea of citizenship as self-protection through emphatic support for the self-defense groups led by Mireles, helps us reflect on the effects these kinds of armed initiatives have on a public discourse on citizenship that is gaining relevance in Mexican society. Rather than subverting the neoliberal logic, this reconfiguration of civil society, together with the emphasis on self-protection, constitutes a neoliberal phenomenon itself.

In his analysis of "the cultural dynamics of Mexican citizenship", Claudio Lomnitz discusses, through various historical moments, how the Mexican state has been unable to extend universal citizenship to all those born in the country (1999: 270). These legal and political formations have involved particular forms of legitimizing exclusion, as well as social strategies, for instance among middle class sectors, to develop personal relations as forms of accessing citizenship -and protection. Lomnitz details how the exercise of citizenship was conditioned by paternalism, clientelism and other nondemocratic practices during the postrevolutionary periods (1999: 293). 

one of the consequences of neoliberal democracy within Latin America is that it "prioritizes civil rights [while] emphasizing the individuals' responsibility for their own and their dependents' wellbeing" (2002: 72). This implies that "from the moment in which the individual is entitled to protect himself, social protection through the state results unnecessary" (2002: 71). These authors echo Nikolas Rose's argument that neoliberal governmentality relies on transferring the state's responsibility to cover society's needs to individual citizens' choices (1999). This neoliberal "self-help" view of citizenship (Assies et al., 2002: 60; Goldstein 2005: 396) and its impacts on Mexican society suggest that the responsibility for justice, as with many other responsibilities, should be in citizens' hands. decades, the Mexican state has reduced public expenditure and promoted privatization and descentralization; while also undergoing a "democratic transition" and state institutional strengthening (Pansters 2012; Leal 2016). In parallel, Mexican efforts to adapt to the global economy included signing international free trade agreements like NAFTA. A neoliberal shift also took place in terms of public policies and social programs, which since the late 1980s sought to ameliorate the impacts of structural adjustment policies on the poor through compensatory health and education programs financed by World Bank and International Monetary Fund loans. A characteristic of these kinds of programs has been their emphasis on "citizen participation", mostly understood in terms of citizen's responsibility and self-care (Zamorano 2008). The neoliberal transition in Mexico has also implied the emergence and strengthening of "civil society" which, according to Alejandra Leal, has been studied as "emerging not only against state authoritarianism, but as a response to neoliberal injustices and exclusions" (2016: 52). Lomnitz suggests that despite this emergence of "massive social movements", the "category of citizen" remains constrained by the persistence of inequality and exclusion (1999: 293). For this reason, uneven access to citizenship might continue to be legitimated under "the pernicious dialectic between the good pueblo and the bad pueblo" (1999: 293). The present analysis of how the self-defense groups have been depicted by some media and urban sectors is helpful to understand how this movement oscillates between those two categories -good pueblo and bad pueblo- in public opinion and at different political moments.

Wil Pansters notes that Mexican neoliberalism also involves a dramatic increase of violence which is not only related to organized crime, but also to "political and electoral violence", as well as to historical processes of inequality related to "land conflicts, socioeconomic marginalization, alcoholism, religious divisions, and factional and family feuds" (Pansters 2012: 11). According to Pansters, all these forms of violence associated with the neoliberal era in Mexico result in a "crisis of security and the judicial system", and in "popular discontent with law enforcement, especially because of the perceived incompetence (or unwillingness) of the authorities to resolve corruption and white-collar crime" (2012: 12). ${ }^{6}$

16 Through an analysis of mob lynching in Cochabamba, Bolivia, Daniel Goldstein explains similar forms of popular discontent as "neoliberal violence", namely, "an inherent component of the neoliberal project and its associated cultural values, which underlie the general condition of insecurity that is both cause and result of popular violence" (2005: 406). 
17 I identify the emergence of self-defense groups in Mexico as a similar phenomenon that cannot be understood as a totally oppositional response to neoliberalism, but rather as intrinsic to its violent logic. Yet, as I stated above, the self-defense groups are not the centre of my analysis, but rather the media and political attention they have received among wider, mainly urban "civil society" sectors that are mobilizing the self-defense struggle in order to promote a specific notion of citizenship based on the premise of selfhelp or corresponsibility. In this respect, Alejandra Leal proposes to understand responsible citizenship as a "dominant common sense" through which "neoliberalism has reactivated and resignified liberal vocabularies about the state, society and citizen, according to which the latter should be responsible for his own wellbeing" (2016: 79).

By carrying the banner for the autodefensa groups and by amalgamating their image in the figure of Mireles, the Frente Nacional de Autodefensas expanded a "neoliberal common sense" of citizenship as self-protection (Leal 2016). In this context, the video produced by this Front creates a message in which public personalities, representing different sectors affected by violence in Mexico, express a common concern against insecurity, impunity, abuse, injustice and, overall, a feeling of being neglected by the state. Despite their differences, all presenters are framed in a similar shot and with the same background and lighting. The tones of their voices are clear and steady, calm yet vigorous. These image and sound effects, together with the "we are all..." motto, generate a sense of uniformity and agreement. At the same time, by displaying each representative speaking directly to the camera framed in a medium shot, the video creates the effect that their presence is not mediated, as if the presenters were directly speaking to, and challenging, each spectator, assumed as a fellow citizen who shares the same concerns. Altogether, the video carefully presents the images and oral discourse as a forceful call for national union for self-organization to "defend ourselves" "because the state is not doing so". In this way the National Front of Self-defense initiative, which could be understood as a civic response to neglect by the neoliberal state, is at the same time articulated in the neoliberal discursive and visual vocabulary of citizen's coresponsibility.

Additionally, by focusing on the image of Mireles as authoritative caudillo, ${ }^{7}$ this argument interestingly builds on the haunting - and mainly urban-middle-class fantasy - of the armed peasant as the central subject of social transformation in Mexico (even when Mireles himself is not a peasant but rather a doctor belonging to a prosperous farmer's family). While the two cases discussed in this article refer to distinct political positions, both of them draw on a neoliberal conception of citizenship as self-protection. After having discussed how images and discourses on self-defense have been mobilized by the "civil society" initiative of the National Front of Self-defense and the Movimiento Ciudadano party; the following section explores how the notion of citizenship as selfprotection has gained resonance in alternative and independent Mexican and international media.

\section{“México Bronco" as a Latent Image}

Photojournalism has contributed to the visibility and legitimacy of self-defense groups. National and international press images presenting positive depictions, mainly produced in the states of Michoacán and Guerrero, have been crucial for visibilizing the contexts of marginality, inequality and violence in which these movements have emerged. Except for 
Irish photographer Ross McDonnell, whose photos mostly circulated in artistic spaces, the most analysed images were produced by Mexican photojournalists working for prestigious national and international photo news agencies such as Agence France-Presse AFP and Associated Press News AP and Cuartoscuro. Most of the images analysed here have been published in magazines and newspapers from the United States, Europe and Mexico. Additionally, a few of the referred images were published in smaller independent electronic work media; one series of images was published in an academic journal; and a few were only circulated through Facebook and twitter. These dynamics of broad circulation in mainly progressive or non-mainstream media, together with the mostly sympathetic depictions of the movement in published images and articles, denotes a strong public interest in the autodefensa movement both in Mexico and internationally.

21 By depicting aspects of daily life and local organizing processes, these images call people to reflect on the conflict and on the reasons why local people resort to these organizations. In addition, many of these images point to the complexity and contradictions of local peoples' involvement in self-defense movements. Furthermore, the possibilities of photographic technologies are instrumental to communicating the emotional aspects of these forms of organization, and to documenting aspects such as distrust, hopelessness and vulnerability that are also part of these processes. Additionally, it is worth acknowledging journalists and photographers' efforts to document these processes especially in light of the risks they take, considering the growing violence exercised both by the state and by the organized crime against journalists in Mexico.

22 In spite of this acknowledgement, I propose a critical reflection about how most visual documentation of the self-defense groups takes part in, and often celebrates, the public articulation of the discourse on citizenship as self-protection. I suggest that this articulation results in an effective mobilization of affects and political empathy among certain publics. On the one hand, the notion of citizenship as self-protection seems to seek continuity with emblematic referents of popular justice and revolutionary fantasies in Mexico. If we think about this in temporal terms, what kind of future can be visualized from this notion of citizenship as self-protection? How does it help to visualize, for the future, the role of citizens and their interaction with the state? What kinds of moral values are displayed? An analysis of self-defense groups' press photography production and circulation is useful in order to engage such questions.

The ways in which the current moment in Mexico is celebrated in national and international media, as well as its future political possibilities, are related to collective fantasies anchored in references to past revolutions. I refer particularly to the Mexican Revolution of 1910, and to the 1990s indigenous mobilizations led by the Zapatista Army of National Liberation. An example of a visual reference to a remote past is a black and white portrait produced by Irish photographer Ross McDonnell in 2013, which presents a frontal shot of a "vigilante" or member of the autodefensa movement of Guerrero. ${ }^{8}$

The man poses standing, holding a long weapon in his hands. He wears a grey shirt, a ski mask and a hat. This image, which takes part of a full series, was published in the photo magazine Wired with an article that analyses the photographers' work (Brook 2014). The aesthetic treatment of the photo series allowed for its circulation not only for informational purposes in one of the main world's news journals, but also within one of the most acknowledged spaces for photographic art, the 17th edition of Paris Photo in 2013. While the anonymity produced by the mask creates an intriguing effect that evokes 
the Zapatista Movement of 1994, the ambrotype technique seems to anchor this portrait in a more remote associated to the 1910 Mexican Revolution. According to film and photography historians, the Mexican Revolution was one of the most documented events of the time -and also one of the most fantasized- through photography and film (see Leyda 1971; De los Reyes 1985; Wood 2009; Wood and De Los Reyes 2016; Rocha 2006; Mraz 2010). This wide production and circulation of images of the Mexican Revolution is also a first reference for written and visual documentation on contemporary self-defense movements. For example, an image by Mexican photojournalist Pedro Pardo shows an aged campesino member of an autodefensa group of Guerrero. Elements like the hat and red handkerchief, as well as the rifle he proudly holds with both hands, are again visual references to both the Mexican Revolution and the 1994 Zapatista movement. The image composition shows him slightly inclined behind the blurred face of another man. His poignant eyes look back at the camera. ${ }^{9}$

In other contemporary images of autodefensa groups, like those from the 1910 Mexican Revolution, multitudes of peasants with weapons now evoke the celebratory narrative of journalist Hernández Navarro's "Hermanos en Armas" (2014), with the idea of Jesús Reyes Heroles that the violent "México Bronco" from the times of the Revolution may return (1977). ${ }^{10}$

Alternatively, images that vindicate women's participation in autodefensa groups such as the ones produced by journalist Sanjuana Martínez in the Michoacán Coast, often turn to the female referents of Mexican Revolution's “Adelitas". ${ }^{11}$

Another image that became iconic of the autodefensas' Adelitas was the one by Purepecha photojournalist Juan José Estrada Serafín of an aged campesino woman wearing a traditional white dress and black rebozo, holding in her arms an AK47 weapon, and laughing directly at the camera.

\section{Armed woman in Michoacán}

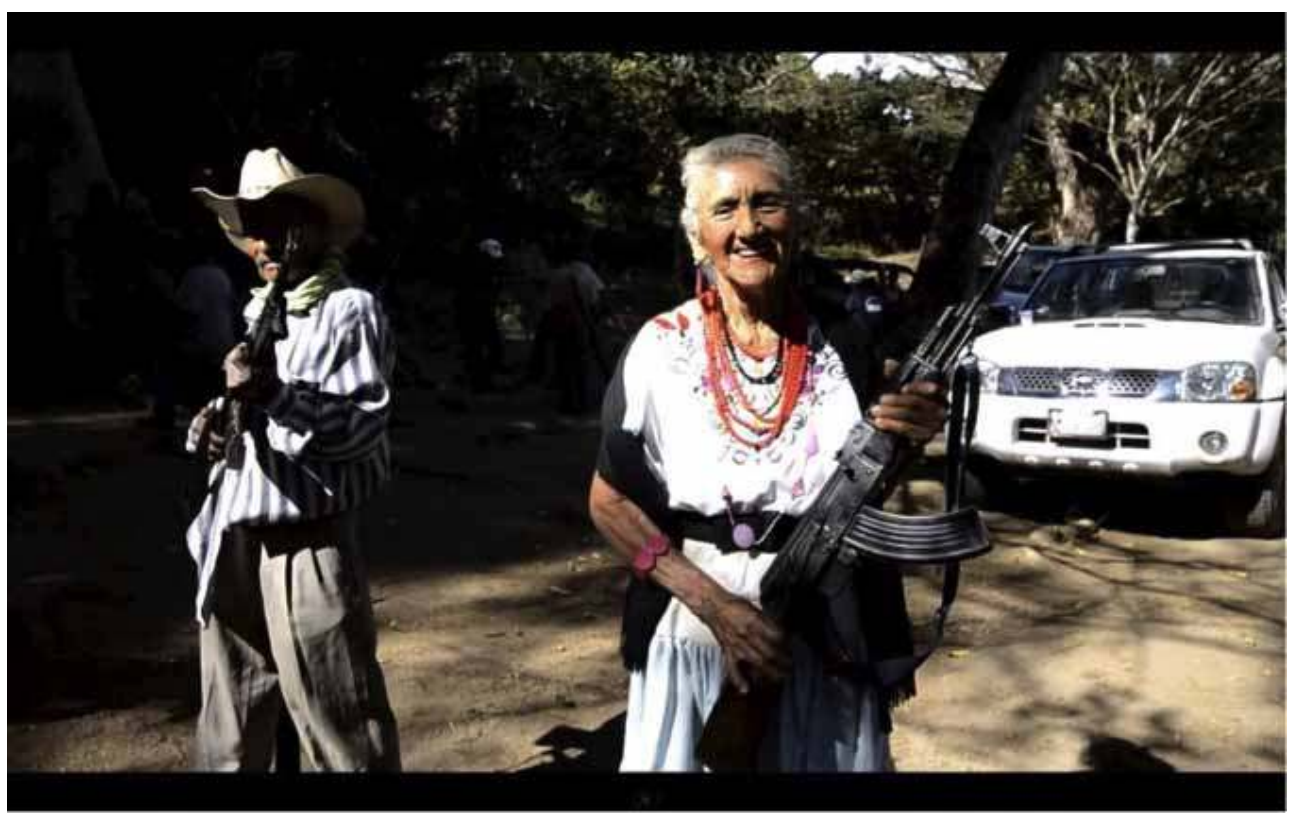

Photo by Juan José Estrada Serafín (Cuartoscuro) 

movements is marked by relatively recent indigenous uprisings in Mexico, which include the EZLN which started in 1994, as clearly shown by an image in which photographer Juan José Estrada Serafín superimposes the portrait of a masked and armed member of community police of Cherán over a mural of 1910 revolutionary Emiliano Zapata, as if the contemporary fighter's cause was backed by the ancient caudillo.

"A community guard member in front of a mural of Zapata."

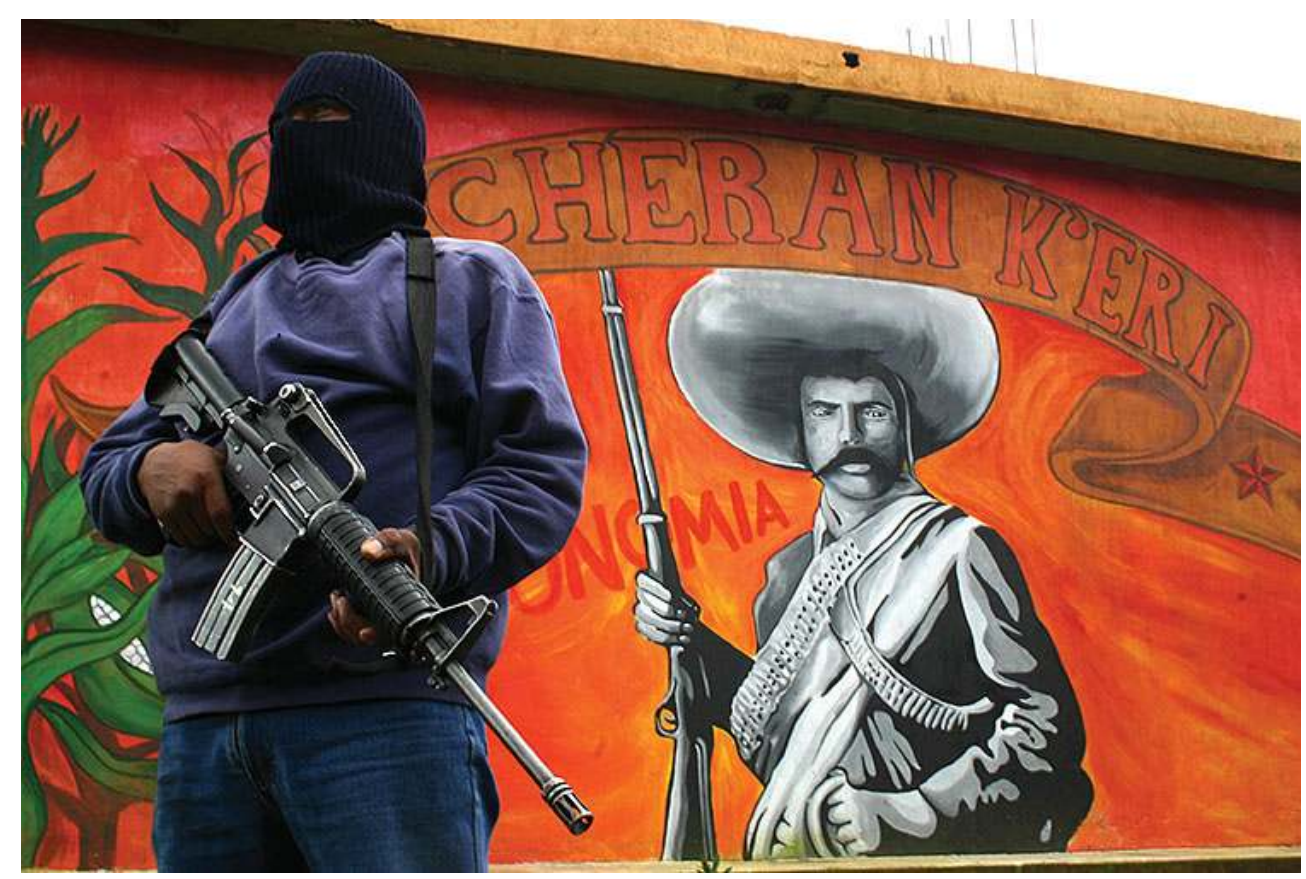

Photo by Juan José Estrada Serafín (Cuartoscuro) published in Ojeda (2014).

30 The pro-autonomy movement started by Purepecha community of Cherán Michoacán was a source of inspiration for autodefensa groups. The community of Cherán organized in 2011 community patrols, barricades and other strategies in order to confront the clandestine felling of its forests by organized crime. By emerging in communities that define themselves as indigenous, these kinds of mobilizations are framed within a larger context in which indigenous people vindicate their rights to self-determination, and which includes the right to implement local forms of government and justice.

31 Academic, journalistic and citizens' references to these kinds of indigenous struggles often acritically attribute to them qualities that may be more related to utopic desires that have become collective or as forms of "cruel optimism" (Berlant 2011), than to other intrinsic qualities of these movements. These attributed qualities include praising these movements as a result of indigenous peoples' collectivity, unity and coherency against enemies that are often explained as external, leaving aside for instance historical 
processes of "structural violence" (Maldonado 2010, 2014), internal political fragmentation and competition for resources within a specific community that doubtlessly impact current regional conflicts (Román 2014, Vázquez León 2010).

I therefore suggest that when acritically associating the phenomenon of self-defense groups with community police processes, much media coverage, and even some academic approaches to the problem in fact obscure the historical and political density in which these kinds of phenomena are immersed. Alternatively, other visual products, such as the documentary "Cartel Land" by Mathew Heineman (2015), have sought to display more critical or balanced approaches to the Autodefensa movement. This documentary sought to make visible not only the organizing strategies and local achievements of this movement; but also its weak moments, Mireles' gender issues, as well as the complex alliances with specific local sectors. At the same time, this documentary does not succeed in breaking with spectacular depictions of local violent action. Altogether, these different approaches contribute to relate these mobilizations to expectations and fantasies of political possibility that are becoming significant amongst different sectors of Mexican civil society.

\section{Photographing Self-defense Groups}

I have briefly discussed the ways in which images of self-defense groups build on previous historical references such as the Mexican Revolution and imagery about indigenous movements in places like Chiapas, Guerrero or Michoacán. I focus now on the technological possibilities of photography and on contemporary photojournalism's aesthetic conventions and strategies of circulation. Photojournalism essays on Michoacán and Guerrero's self-defense groups, which were frequently published and even won prizes, raise questions about the ways in which current photojournalism, from its already established aesthetics, contributes to mobilizing desires, hopes, frustrations and political values that engage with the growingly predominant discourse of citizenship as selfprotection. In this regard, how do these images add to the assumed mission of citizens' self-defense of building a more promising vision of the future?

The work of Mexican journalists has been affected in various ways by disputes between organized crime and the government for control of information. On the one hand, many journalists have been threatened and even killed by organized crime; while many others became instrumental for covering events in ways that suited the cartels and even for designing the personal image of capos like Servando Gómez Martínez "La Tuta", as scandals on this issue demonstrated in $2014 .{ }^{13}$ On the other hand, there is a growing governmental concern for protecting its reputation. For example, during a 2014 interview, renowned Mexican photojournalist Pedro Valtierra expressed his critical posture vis-à-vis the governmental initiative to make a pact with the national press in order to cease reproducing and amplifying messages circulated by cartel groups. Although Valtierra agrees with not reproducing narco groups' brutality, he argues that "journalism has a social commitment and our responsibility is to tell the story as it is, whether we like it or not." ${ }^{14}$ The Mexican weekly news magazine Proceso stated a similar position in 2016 through its publication of a series of explicitly violent, while often highly aesthetic, archive images of the "narcoguerra" ${ }^{15}$ Despite Valtierra and other Mexican journalists' opposition to this initiative, most Mexican news organizations signed this agreement with the government. ${ }^{16}$ 

reality" establishes a dialogue with certain aesthetic conventions within contemporary photojournalism. For example, many photographers seek an intimate approach by privileging the physical closeness of the camera -and of the photographer- with autodefensa people or other photographed subjects, generally with a somewhat distorted image provoked by a wide-angle lens. This closeness results in an effect of being in the middle of action, and often creates empathy with the photographed subjects. Examples of this search for closeness include a photo taken by Mexican photojournalist Eduardo Verdugo in the middle of a confrontation, in which a group of four armed autodefensas is shooting long weapons while hiding behind a truck. The wide-angle perspective allows the photographer to locate the autodefensa members in the middle of other cars, provoking a dynamic sense of space accentuated by their positions while shooting. ${ }^{17}$ perhaps to accentuate the testimonial effect of presence and verifiable data. Additionally, in agreement with contemporary photojournalistic aesthetics, both images privilege the sense of taking part in action, which implies immediacy and spontaneity.

In other cases, posing and staging are key coverage elements because they create a more direct effect of interaction with subjects, as three images of members of self-defense groups in Michoacán by Saúl Ruiz show. In one of them a man wearing a white autodefensa shirt poses standing in a relaxed pose, resting his arm on his rifle, in a backyard (Ruiz 2014, photo 7). The second one shows a woman also posing with her weapon in a house that autodefensas confiscated from cartel members in Michoacán (Ruiz 2014, photo 9). The third picture shows a group shot of 11 autodefensa members pointing their long weapons to the camera in a backyard.

Members of the group lead by Comandante Cinco pose in the house of a narco-trafficker known as "el Botas"

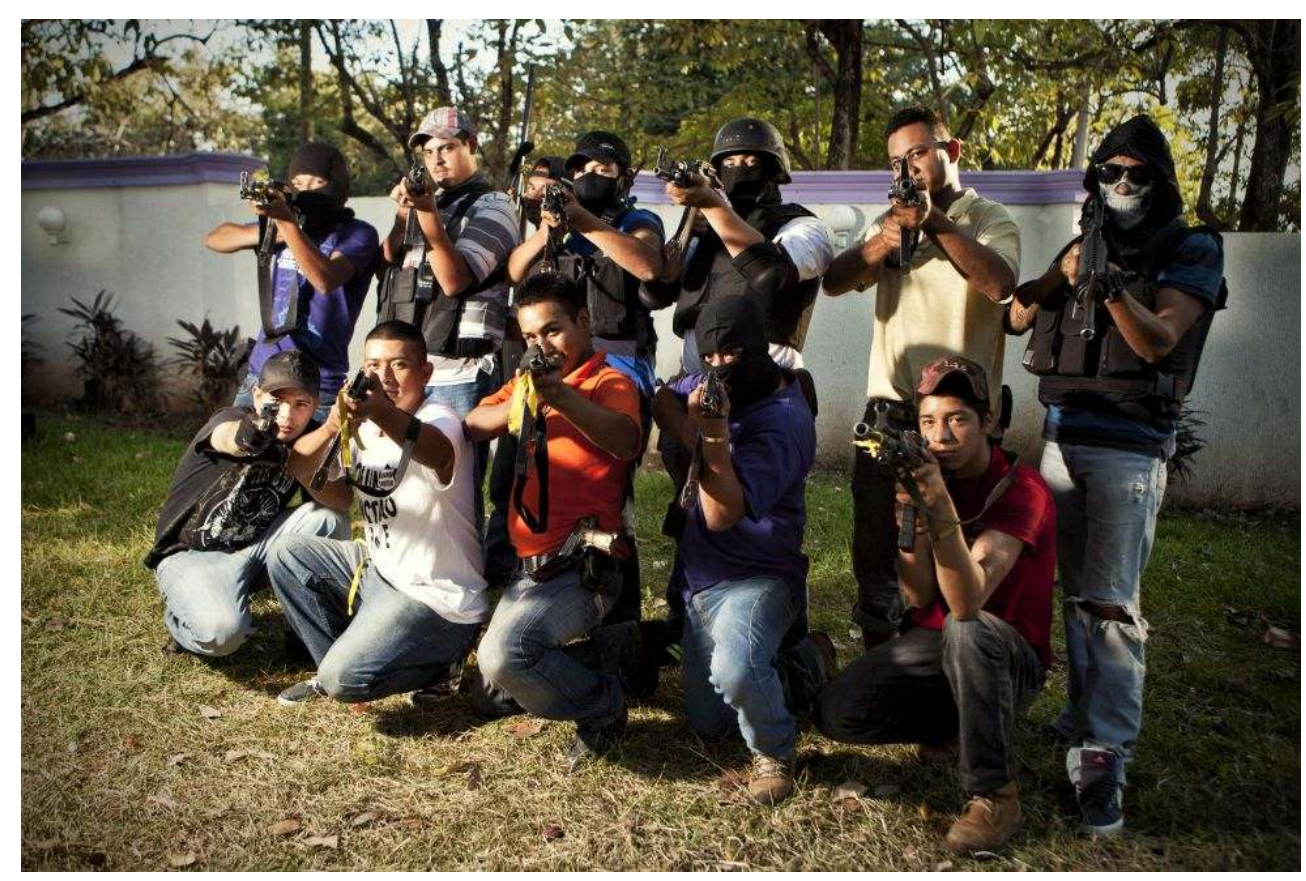

Photo by Saúl Ruiz published in Ruiz (2014) 
These images exemplify some common aesthetic tendencies of contemporary photojournalism which convey specific narratives of reality about the self-defense movement. For instance, the closeness of the camera to depict situations evokes a sense of action, while also affirming the photographer's access merit for being there. Alternatively, the aesthetic resource of producing posed portraits evokes a sense of intimacy and dignity by allowing self-defense members to interact with the photographer in more ludic and self-representational ways.

In addition to aesthetic tendencies, we should reflect on the conditions of production and the possibilities of circulation not only in the printed press, but mainly in electronic media and in their fragmentation, reutilization, and multiplication via social media networks. From its origins photographic technology involved an ambiguity between the real, objective possibility of capturing an object's image, and the ambiguous and subjective elements of framing and separation from its original context. The technological possibilities of current electronic media boost this ambiguous quality by approximating publics to given realities in more immediate, realistic, and massive ways; but also by obscuring or even parodying it. Three connected images on the self-defense groups exemplify these contemporary forms of commenting on Mexican reality. On February 24, 2014, Time Magazine's cover presented a portrait of former Mexican President Enrique Peña Nieto, wearing a blue suit. The main cover text signals the title of Michael Crowley's article included in this edition: "SAVING MEXICO. How Enrique Peña Nieto's sweeping reforms have changed the narrative in his narco-stained Nation". Within Mexico, this cover raised great controversy and outrage because four years after Time's publication, Peña Nieto's presidential period proved to be the most violent one in recent history. ${ }^{18}$ Among the discursive and visual critiques to Time's cover, several mocking images were immediately circulated as memes. One of them substitutes Peña Nieto's portrait with a full body version of the old woman holding an AK47. The central text uses the same phrase: "Saving Mexico", but then includes a sub-heading in the right lower corner, with the same white typography: “... from Peña Nieto". A similar meme substitutes Peña Nieto's portrait with one of José Manuel Mireles wearing the President's impeccable suit. This time the original text is untouched. 
Cover Page. Time Magazine. February 24, 2014.

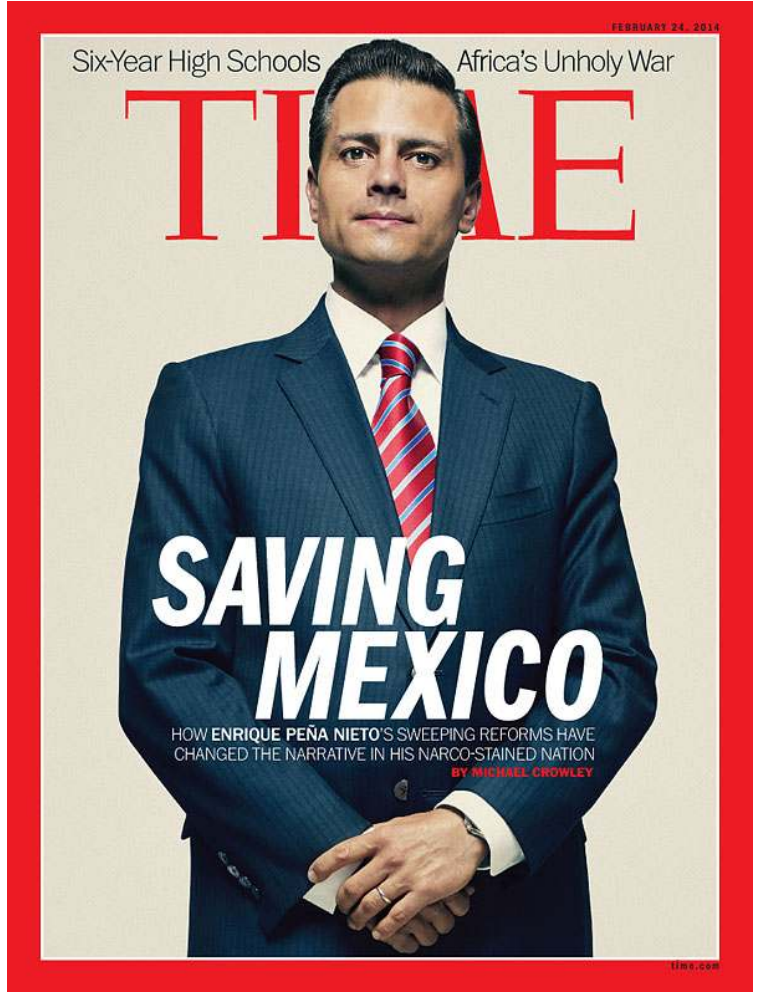

Photograph by Peter Hapak for Time http://content.time.com/time/covers/ pacific/0,16641,20140224,00.html (accessed June 27, 2018)

\section{Memes of Time Magazine cover page.}
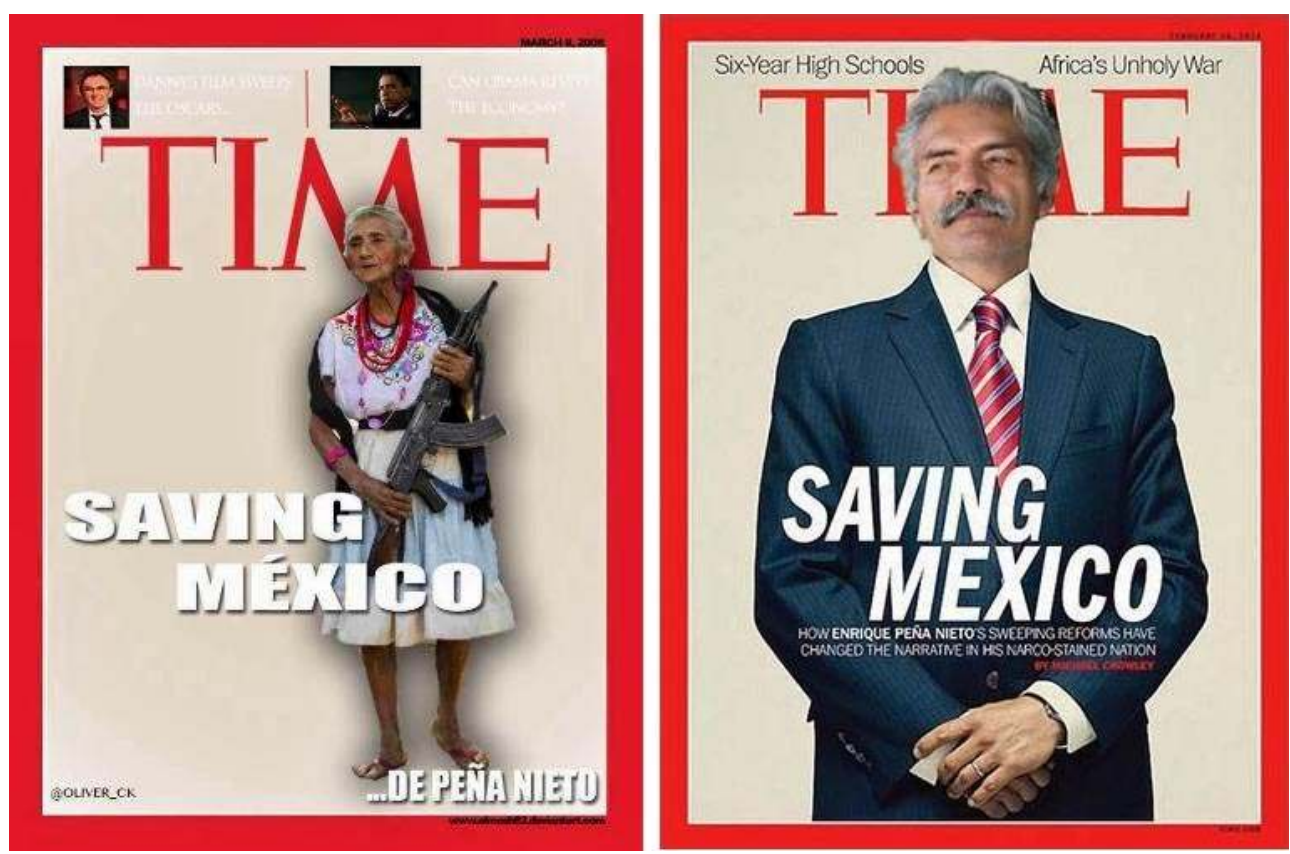

Published by Borderland Beat. http://www.borderlandbeat.com/2014/02/epn-mexicos-savior-saystime-magazine.html (accessed April 24, 2018) 
have, therefore, a visual repertoire that nostalgically evokes the multitudinous resurrection of a "México Bronco", the armed struggles of people extremely affected by narco-violence and who now work as models of strength, but also as utopic fantasies of them as saviours and guardians of our justice.

Those who lead these struggles are often fantasized as Others who are coherent and authentic, rooted in the land, in their ways of organizing, in their self-determination. This image fuses itself with a peasant with a hat, a romanticized Other whose contradictory and dramatic implication with weapons make it possible for many others, often others who are more privileged, to celebrate this misfortune by mechanically repeating: "I am self-defense. We are all self-defense".

42 In this regard, I would like to close this article by asking how these kinds of images mobilize collective affects and fantasies of the future, and how this mobilization adds to the growing tendency to conceive citizenship as self-protection?

Let us think, for example, about how the picture of a child holding a long weapon by Félix Márquez evokes many others of children with arms. This image communicates the irremediable situation that provoked this ordinary relationship of the child with the gun. This relationship constitutes a contradictory metaphor containing a future that is both promising and threatening.

A child tries to help his father arrange weapons at a checkpoint set up by the Self-Defense Council of Michoacan, (CAM), in Tancitaro, Mexico, on January 16, 2014.

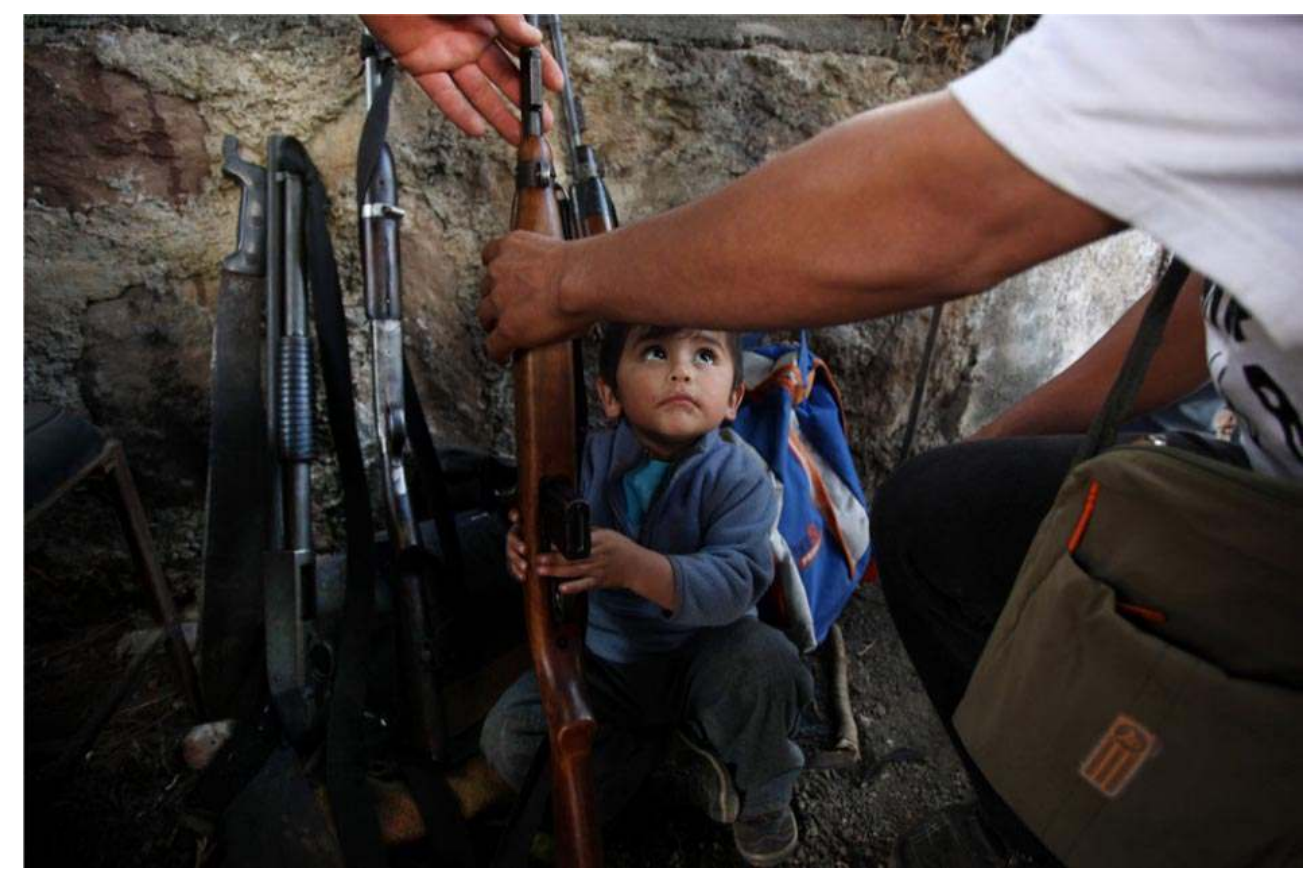

Photo by Félix Márquez (AP Photo) published in Taylor (2014)

A couple of other images show how punishment can escape collective action and become individual and spontaneous responses of rage and excess. In one of them taken by AP Agency, a rural man is trying to strangle a policeman while another man tries to stop him. ${ }^{19}$ Another image, by Bernardino Hernández, shows two presumed cartel members captured and escorted by autodefensas in Michoacán, while an armed autodefensa kicks one of them. ${ }^{20}$ 

led both by campesino and well-established agricultural producers whose families and economies have been affected by cartel violence. In this article I have discussed how these movements, and particularly their emphasis on "self-protection", have inspired or echoed among urban middle-class sectors neoliberal commonsensical notions about citizens' corresponsability for security. For this purpose, I have focused on the ways in which a political party's promotional strategies on the one hand, and photojournalism on the other, have visually referred to the autodefensas phenomenon.

51 Although the images analysed in this essay were produced during the first years of the autodefensa movement, the shift of the political scenario marked by the election of MORENA populist representative Andrés Manuel López Obrador in July 2018 opens the question of how this movement is portrayed and used by this new regime which openly declares its opposition to neoliberalism. Although it is beyond the reach of this article to address the reconfiguration of the self-defense movement under the new government, it is worth noting how the presence of José Manuel Mireles, and the overall discourse of the self-defense movement, took a new direction in national politics after his release from prison in May 2017. A few months after his liberation, Mireles initiated public talks, created the Fundación Mireles to work with narco-war victims in his region, and published a book titled under the same slogan used by the National Front, "Todos somos autodefensas" (2017). In 2018 Mireles appeared in political events in Michoacán during the presidential campaign of Andrés Manuel López Obrador, and he even tried to enrol as 
a Plurinominal candidate for the national congress for the Movimiento de Regeneración Nacional, MORENA. In other words Mireles, who still presents himself as a representative of the self-defense movement of Michoacán, is now working in the civil, legal realm to build public opinion, perhaps with the aim of becoming a political representative. Additionally, it is significant that during his participation in the 2014 meeting to create the National Front for Self-Defense, Mireles suggested the creation of a National Guard, an entity which is indeed acknowledged in the Constitution and which, he suggested, could combine the efforts of active self-defense members in order to build a legal initiative for national security. ${ }^{23}$ Five years later, President Andrés Manuel López Obrador proposed the controversial initiative for creating a National Guard in order to face the current security emergency. ${ }^{24}$ Although constituted by army, navy and police forces, the notion of a National Guard ambiguously alludes to civil participation either through national service or through drafting citizens. ${ }^{25}$ The energetic public support that Mireles has manifested in favor of this initiative -he even gathered signatures to present to the Senate- suggests that the National Guard could be a vehicle for vindicating and creating legal possibilities for the self-defense movement. At the same time, the cautious but still positive acknowledgement that Lopez Obrador is making of Mireles and the self-defense movement suggests that their rhetoric and images are legitimate for the new state project. In other words, returning to Lomitz's discussion on the differentiated access to citizenship under arguments of "good pueblo and the bad pueblo", it is possible that the new regime may provide the "bad pueblo" with some legitimacy with the help of the positive impacts that the images and rhetoric of the autodefensas movement have made on different sectors of Mexican society. It remains early to see how the ongoing government transformations impact on the access and exercise of citizenship in Mexico.

At the same time, the growing idealization of the campesino armed struggle as the last resource for "awakening" national consciousness, may lead to overlooking the complexities and power dynamics that rural areas hit by narco-violence are currently experiencing. Together with the relationships that the current regime might develop with Mireles and the autodefensa movement, this represents a challenge, questioning the symbolic relevance that revolutionary references have in the current transformations of the Mexican state and in its resulting redefinitions of citizenship.

\section{BIBLIOGRAPHY}

\section{Books and articles}

Assies, Willem, Marco Calderón and Salman, Ton. 2002. Ciudadanía, cultura política y reforma del Estado en América Latina. Salamanca: Universidad de Salamanca.

Baranda, Antonio. 2014. Propone Mireles Guardia Nacional. Reforma, May 28, 2014. https:// www.reforma.com/aplicacioneslibre/articulo/default.aspx? $\mathrm{id}=245145 \& \mathrm{md} 5=$ be 6 ece $2993 \mathrm{c} 6 \mathrm{ba} 4 \mathrm{df} 03 \mathrm{cbe} 07850 \mathrm{fd} 7 \mathrm{~d} 2 \& \mathrm{ta}=0 \mathrm{dfdbac} 11765226904 \mathrm{c} 16 \mathrm{cb} 9 \mathrm{ad} 1 \mathrm{~b} 2 \mathrm{efe}$ (accessed March 20, 2019). 
Berlant, Lauren. 2011. Cruel optimism. Durham, NC: Duke University Press.

Beauregard, Luis Pablo (L.P.B). 2018. El Gobierno de Peña Nieto desbanca al de Felipe Calderón como el más violento de México. El País, 4/22/2018. https://elpais.com/ internacional/2018/04/21/mexico/1524336593_689776.html (accessed May 23, 2019)

Brook, Pete. 2014. Meet the Ragtag Vigilantes At War With Mexico's Cartels. Wired, Photo. May 23. https://www.wired.com/2014/05/Ross-Mcdonnell/ (accessed, April 24, 2018).

Carrión, Lydiette. 2014. Mujeres en la 'guerra' de Michoacán. El Universal, 1/24/2014. http:// archivo.eluniversal.com.mx/nacion-mexico/2014/mujeres-en-la-34guerra-34-demichoacan-982042.html (accessed April 24, 2018).

De Los Reyes, Aurelio (ed.). 1985. Con Villa en México: testimonios sobre camarógrafos norteamericanos en la Revolución, 1911-1916. Mexico: UNAM.

Eiss, Paul. 2014. The Narcomedia: A Reader's Guide. Latin American Perspectives 41:2 (March 2014): 78-98.

Estey, Myles. 2013. Mexican vigilantes take over for police: they don't need no stinkin' badges. The Star, April 27. https://www.thestar.com/news/world/2013/04/27/ mexican_vigilantes_take_over_for_police_they_dont_need_no_stinkin_badges.html. (accessed June 27, 2018).

Goldstein, Daniel M. 2005. Flexible Justice: Neoliberal Violence and 'Self-Help' Security in Bolivia. Critique of Anthropology 25(4): 389-411. DOI: 10.1177/0308275X05058656

Guerra Manzo, Enrique. 2015. Las autodefensas de Michoacán: Movimiento social, paramilitarismo y neocaciquismo. Política y Cultura 44: 7-31.

Hernández Navarro, Luis. 2014. Hermanos en armas. Policías comunitarias y autodefensa. Mexico: Secretaría de Cultura Ciudad de México, México DF.

Koselleck, Reinhart. 2004. Futures Past: On the Semantics of Historical Time. New York: Columbia University Press.

Leal Martínez, Alejandra. 2016. Neoliberalismo, Estado y Ciudadanía. Relaciones. Estudios de Historia y Sociedad 147: 51-84.

Leyda, Jay. 1971. Films Beget Films. A study of the Compilation. New York: Hill and Wang.

Lira, Andrés. 1973. Sobre Fernando Díaz Díaz, Caudillos y Caciques (Antonio López de Santa Anna y Juan Álvarez). México : El Colegio de México, 1972. 354 p. (Centro de Estudios Históricos, Nueva Serie, 15). Historia Mexicana 22(4): 624-626.

Lomnitz, Claudio. 1999. Modes of Citizenship in Mexico. Public Culture 11(1): 269-293.

López Obrador, Andrés Manuel. 2018. Plan Nacional de Paz y Seguridad 2018-2024. P. 15. https:// lopezobrador.org.mx/wp-content/uploads/2018/11/Plan-Nacional-de-Paz-y-Seguridad_.pdf (accessed March 20, 2019).

Maldonado, Salvador. 2010. Los márgenes del Estado mexicano." Territorios ilegales, desarrollo y violencia en Michoacán. Zamora: El Colegio de Michoacán.

Maldonado Aranda, Salvador. 2014. El futuro de las autodefensas michoacanas. Nexos 3.4.2014.

Martínez, Sanjuana. 2014. Seguiremos alzadas para defender a nuestras familias. La Jornada 17.8.2014. http://www.jornada.unam.mx/2014/08/17/politica/008n1pol). (accessed April 25, 2018). 
McDonnell, Ross. 2013. Auto Defensa: Rough Justice in Mexico's Lawless Mountains. Time Magazine 12.2.2013 http://time.com/3796695/auto-defensa-rough-justice-in-mexicos-lawless-mountains/. (accessed June 27, 2018).

Mireles Valverde, José Manuel. 2017. Todos somos autodefensas: El despertar de un pueblo dormido. Mexico City: Grijalbo.

Mraz, John. 2010. Looking for Mexico: Modern Visual Culture and National Identity. Durham, NC: Duke University Press.

Ojeda, Lorena. 2014. Communities Up in Arms. Berkeley Review of Latin American Studies, Spring 2014. https://clas.berkeley.edu/research/mexico-communities-arms (accessed June 27, 2018).

Ortiz Escamilla, Juan. 2019. Guardia nacional o policía militar. Nexos, 1.1.2019. https:// www.nexos.com.mx/?p=40751 (accessed March 20, 2019).

Pansters, W. G. 2012. Zones of State-making: Violence, Coercion, and Hegemony in Twentiethcentury Mexico. In Violence, Coercion, and State-Making in Twentieth-Century Mexico. The Other Half of the Centaur. W. G. Pansters, ed. Pp. 3-42. Stanford: Stanford University Press

Piccato, Pablo. 2017. A History of Infamy. Crime, Truth, and Justice in Mexico. Oakland, University of California Press.

Reyes Heroles, Jesús. 1977. Discurso pronunciado por el Lic. Jesús Reyes Heroles, Secretario de Gobernación, en la sesión solemne en que el C. Ing. Rubén Figueroa, Gobernador Constitucional del Estado de Guerrero, rindió su segundo informe de gobierno ante la H. XLVIII Legislatura de esa entidad. Reforma Política, Gaceta Informativa de la Comisión Federal Electoral, No. 1: IX-XIII. México: SEGOB-Comisión Federal Electoral

Rocha, Gregorio C. 2006. 'La venganza de Pancho Villa': A Lost and Found Border Film. In $F$ is For Phony: Fake Documentary and Truth's Undoing. Alejandra Juhasz and Jesse Lerner, eds., Pp. 50-58. Minneapolis: University of Minnesota Press

Román Burgos, Denisse. 2014. El espejismo del orden. Etnografía histórica sobre política local en Cherán, Michoacán (1856-2014). PhD. Dissertation, Centro de Estudios Antropológicos, El Colegio de Michoacán, Mexico.

Rose, Nikolas. 1999. Powers of Freedom: Reframing Political Thought. Cambridge: Cambridge University Press.

Ruíz Mata, Saúl. 2014, Michoacán, el polvorín mexicano. El País, January 18. 2014. https:// elpais.com/elpais/2014/01/18/album/1390078835_415742.html\#foto_gal_7. (accessed June 27, 2018).

Taylor, Alan. 2014. Mexico's Vigilantes. The Atlantic, May 13 2014. https://www.theatlantic.com/ photo/2014/05/mexicos-vigilantes/100734/. (accessed June 27, 2018).

Vázquez León, Luis. 2010. Multitud y distopía: ensayos sobre la nueva condición étnica en Michoacán. Mexico: Universidad Nacional Autónoma de México.

Wood, David M. 2009. Memorias de una mexicana: la revolución como monumento fílmico. Secuencia. Revista de historia y ciencias sociales, (75). 147-170.

Wood, David M. and De Los Reyes, Aurelio. 2016. Revolución, compilación, conmemoración: Salvador Toscano y la construcción de caminos en el México posrevolucionario. In Cine mudo latinoamericano. Inicios, nación, vanguardias y transición. Aurelio De Los Reyes and David Wood (eds.) Pp. 87-108. México: UNAM. 
Zamorano, Gabriela, ¿Desarrollando capacidades? Pobreza, “oportunidades” y ciudadanía neoliberal. Bajo el Volcán, 7 (12), 2008, 67-88.

Films

Grillonautas. (uploaded 2014.) Todos Somos Autodefensas. 2 min. https://www.youtube.com/watch? $\mathrm{v}=$ mi0AHbgKOxs (accessed April 24, 2018).

Heineman, Mathew. 2015. Cartel Land. 100 min.

Vapormipatria. 2012 upload. Cómo nace Yo soy 132 Video original de yo soy $131.11 \mathrm{~min}$. https:// www.youtube.com/watch?v=hca6lzoE2z8 (accessed April 24, 2018).

\section{NOTES}

1. Todos Somos Autodefensas. https://www.youtube.com/watch?v=mi0AHbgKOxs (accessed April 24, 2018).

2. Yo soy 132. https://www.youtube.com/watch?v=hca6lzoE2z8 (accessed April 24, 2018).

3. The referred self-defense movement constitutes a group which decided not to comply with the Mexican government's call to constitute the "Fuerzas Rurales" (Rural Force) in May 2014.

4. Cited in Michel, Víctor Hugo. "Autodefensas convocarán la "protección ciudadana" in Milenio, 27/05/2014.

5. See examples of these kinds of images in the Movimiento Ciudadano facebook profile: https:// www.facebook.com/MovCiudadanoMX/photos/

a.121955827900350.23296.118921468203786/633476073414987/. (accessed June 27, 2018).

6. At the same time, Pablo Piccato demonstrates that, for the case of Mexico, the conception of justice as a realm beyond the state's responsibility does not emerge with neoliberalism, but rather marks a historical continuity with the postrevolutionary period since the first decades of the twentieth century (2017). Piccato argues that after the 1910 revolution, Mexico did not become "a successful example to transition to democracy and the rule of law", which resulted in a "broadly shared tolerance in Mexican civil society for extrajudicial punishment and the victimization of the innocent. This tolerance developed despite the parallel emergence of critical perspectives sharply condemning the inability of the state to seek and acknowledge the truth" (2017:1).

7. Authors including Moisés González Navarro and Fernando Díaz Díaz define caudillo as a leader with an urban mentality and national influence who fights for social change and seeks to achieve legal acknowledgement (Lira 1973: 625).

8. See: 'Vigilante', 10"x8". Ambrotype on glass. 2013. "A masked member of the 'auto defensa' committee in Ayutla de los Libres, a small pueblo in the La Costa Chica region of Guerrero state, Mexico." Image by Ross McDonnell published in Brook (2014). https://www.wired.com/2014/05/ Ross-Mcdonnell/. (accessed, April 24, 2018).

9. See: "Armed residents - community police-take part in the March for Justice and Dignity in Ayutla de los Libres, on March 2, 2013, in the southwestern State of Guerrero, Mexico." Image by Pedro Pardo (AFP) published in Estey (2013).

10. See: "Armed residents - community police-take part in the March for Justice and Dignity in Ayutla de los Libres, on March 2, 2013, in the southwestern State of Guerrero, Mexico." Image by Pedro Pardo (AFP) published in Estey (2013).

11. See: "Portrait of Claudia Yazmín Mercado, Autodefensa from Coahuanaya." Photo by Sanjuana Martínez, published in Martínez (2014).

12. See: "Idalia, Comandanta Bonita". Photo by Jorge Serratos (El Universal) published in Carrión (2014). 
13. See for example a video published by influential Mexican journalist Carmen Aristegui in September 2014 in which the leader of the Caballeros Templarios cartel, Servando Gómez ("La Tuta") meets with two mainstream-media reporters. (https://www.youtube.com/watch? v=HRLB3gpcRmkMVS, accessed April 24, 2018).

14. Valtierra, Pedro. 2014. "Los periodistas no podemos esconder la violencia" in Clasesdeperiodismo.com http://www.clasesdeperiodismo.com/2014/02/24/pedro-valtierra-losperiodistas-no-podemos-esconder-la-violencia/ (Last accessed April 24, 2018).

15. See: Procesofoto, "10 años de narcoguerra en imágenes", December 11, 2016 https:// www.proceso.com.mx/465931/10-anos-narcoguerra-en-imagenes. (accessed June 27, 2018).

16. See: "Mexican media sign drug reporting pact" in The Guardian, 3/25/2011 in https:// www.theguardian.com/media/greenslade/2011/mar/25/press-freedom-mexico (accessed April 24, 2018). On this initiative see also Eiss (2014).

17. See: "Men belonging to the Self-Defense Council of Michoacan, (CAM), engage in a firefight while trying to flush out alleged members of the Knights Templar drug cartel from Nueva Italia, Mexico, on January 12, 2014." Photo by Eduardo Verdugo published in Taylor (2014).

18. See Luis Pablo Beauregard (L.P.B). 2018.

19. AP Photo."Vigilantes attack a local police officer during clashes between police and selfdefense groups in the town of Tixtla, Mexico, on August 26, 2013." Photo published in Taylor (2014).

20. See: "A community policeman kicks a man allegedly suspected of participating in an ambush against them near the town of La Concepcion, Mexico, on April 4, 2014." Photo by Bernardino Hernández (AP Photo), published in Taylor (2014).

21. See: "A man belonging to the Self-Defense Council of Michoacan kisses a woman in the main square of the town of Nueva Italia, on January 13, 2014." Photo by Eduardo Verdugo (AP Photo), published in Taylor (2014).

22. See: "An unidentified armed man from a self-defense group stands with his weapon at the entrance of Apatzingan in Michoacan state, Mexico, on February 9, 2014." Photo by Marco Ugarte (AP Press), published in Taylor (2014).

23. See Baranda 2014.

24. See López Obrador 2018.

25. See Juan Ortiz Escamilla 2019.

\section{ABSTRACTS}

This article examines the production and circulation of images around the autodefensa movement in Mexico. Since 2013, this movement has confronted narco-violence mainly in rural Michoacán, Mexico, swiftly gaining a presence amongst national and international mainstream and independent media. The autodefensas' appeal for "self-protection" gained sympathy both with entrepreneurial classes and popular and peasant sectors. This article analyses how media images around this movement relate to neoliberal notions of citizenship as self-protection, and how its popularity is nourished by historical fantasies about the armed peasant as a central agent of political transformation. The analysis includes a preliminary exploration of the ways in which these images engage with the reelaborations of citizenship and security that the current populist 
government of President Andrés Manuel López Obrador is making as part of the new state project.

Cet article examine la production et la circulation d'images autour du mouvement "autodefensa" au Mexique. Depuis 2013, ce mouvement s'est attaqué à la narco-violence principalement dans les zones rurales du Michoacán, au Mexique. Il a rapidement acquis une présence dans les médias nationaux et internationaux traditionnels et indépendants. L'appel de l'autodéfense à "l'autoprotection" a gagné la sympathie des classes entrepreneuriales, des secteurs populaires ainsi qu' agricoles. Cet article analyse comment les images médiatiques autour de ce mouvement se rapportent aux notions néolibérales de citoyenneté en tant qu'autoprotection, et comment sa popularité se nourrit des fantasmes historiques sur le paysan armé comme agent central de la transformation politique. L'analyse comprend une exploration préliminaire de la manière dont ces images s'inscrivent dans les réflexions sur la citoyenneté et la sécurité que le gouvernement populiste actuel du président Andrés Manuel López Obrador mène dans le cadre du nouveau projet étatique.

Este artículo examina la producción y circulación de imágenes alrededor del movimiento de autodefensa en México. Desde 2013, este movimiento ha confrontado la narco violencia principalmente en el área rural de Michoacán, México, ganando inmediatamente una presencia en la prensa corriente y la independiente. El atractivo de las autodefensas para la "auto protección" ganó simpatía tanto entre las clases empresariales como en los sectores populares y campesinos. El artículo analiza cómo las imágenes de prensa alrededor de este movimiento se relacionan con nociones neoliberales de ciudadanía y auto protección, y cómo su popularidad se alimenta de fantasías históricas sobre el campesinado armado como agente central para la transformación política. El análisis incluye una exploración preliminar de las formas en las que estas imágenes se vinculan con la reelaboración de nociones de ciudadanía y seguridad que el actual gobierno populista del presidente Andrés Manuel López Obrador está haciendo dentro de su nuevo proyecto estatal.

\section{INDEX}

Palabras claves: grupos de autodefensa, fotoperiodismo, video, narco violencia, autoprotección, ciudadanía neoliberal, Michoacán, México

Mots-clés: autodefensa groupes, photojournalisme, vidéo, narco-violence, auto-protection, citoyenneté néolibérale, Michoacán, Mexique

Keywords: autodefensa groups, photojournalism, video, narco-violence, self-protection, neoliberal citizenship, Michoacán, Mexico.

\section{AUTHOR}

\section{GABRIELA ZAMORANO VILLARREAL}

El Colegio de Michoacán, Centro de Estudios Antropológicos zamoranog@gmail.com

Ph.D., Anthropology Department of the City University of New York (2008). She conducted postdoctoral research on racial photography in Bolivia at the Musée du Quai Branly in Paris in 2009. She is the author of "Indigenous Media and Political Imaginaries in Contemporary Bolivia" (Nebraska 2017), and co-author of "De Frente al Perfil. Retratos Raciales de Frederick Starr" (Colmich 2012). Her current research projects include a study of the production and circulation 
of community and family photographic and audio-visual archives in Mexico and Bolivia; and the direction of a documentary film project on the archives of Bolivian photographer Julio Cordero. 